\title{
Correction to: What matters to you when the nursing home is your home: a qualitative study on the views of residents with dementia living in nursing homes
}

Agnete Nygaard ${ }^{1,2^{*}}$, Liv Halvorsrud ${ }^{1}$, Ellen Karine Grov ${ }^{1}$ and Astrid Bergland ${ }^{1}$

\section{Correction to: BMC Geriatr 20, 227 (2020) \\ https://doi.org/10.1186/s12877-020-01612-w}

Following publication of the original article [1], we have been notified that the title is not correct. The correct title should be as per below:

What matters to you when the nursing home is your home: a qualitative study on the views of residents with dementia living in nursing homes.

Published online: 18 February 2021

\section{Reference}

1. Nygaard, et al. What matters to you when the nursing home is your home: a

qualitative study on the views of residents with dementia living in nursing

homes. BMC Geriatr. 2020;20:227. https://doi.org/10.1186/s12877-020-01612-w.

The original article can be found online at https://doi.org/10.1186/s12877020-01612-w.

* Correspondence: s98209@oslomet.no

'OsloMet-Metropolitan University, Faculty of Health Sciences, 0130 Oslo,

Norway

${ }^{2}$ Lørenskog Municipality, Centre for Development of Institutional and Home

Care Services, Lørenskog, Akershus, Norway

(c) The Author(s). 2021 Open Access This article is licensed under a Creative Commons Attribution 4.0 International License, which permits use, sharing, adaptation, distribution and reproduction in any medium or format, as long as you give appropriate credit to the original author(s) and the source, provide a link to the Creative Commons licence, and indicate if changes were made. The images or other third party material in this article are included in the article's Creative Commons licence, unless indicated otherwise in a credit line to the material. If material is not included in the article's Creative Commons licence and your intended use is not permitted by statutory regulation or exceeds the permitted use, you will need to obtain permission directly from the copyright holder. To view a copy of this licence, visit http://creativecommons.org/licenses/by/4.0/. The Creative Commons Public Domain Dedication waiver (http://creativecommons.org/publicdomain/zero/1.0/) applies to the data made available in this article, unless otherwise stated in a credit line to the data. 